\title{
Evaluation of Aeromodelling Coaching System
}

\author{
Liesda Oktoviani Nugraha \\ Master of Sports Science Program \\ Universitas Negeri Yogyakarta \\ Yogyakarta, Indonesia \\ liesdaok@gmail.com
}

\author{
Wara Kushartanti \\ Master of Sports Science Program \\ Universitas Negeri Yogyakarta, Indonesia \\ Yogyakarta, Indonesia \\ wkushartanti@gmail.com
}

\begin{abstract}
The aim of this research was to carry out an evaluation of Federation Aero Sport Indonesian Aerospace coaching program to understand the effectiveness and efficiency of the process and system of coach aeromodelling training in preventing athletes' injury according to coaching and sport physiology. This research was an evaluation research with the use of CIPP as the data collection technique (Contex, Input, Proces, and Product). The subjects in this study were people who knew about PB FASI aeromodelling coaching system. The data analysis technique employed was used to describe and interpret data from each component that was used to evaluate qualitative data. The results showed that the exercise program at Federation Aero Sport Indonesian does not yet have a good workout program. The arrangement of programs of physical and
\end{abstract}

\section{INTRODUCTION}

Athletes, especially young ones, are huge investments for families and nations. Growing and developing every child is very important to support the future. Athletes, especially the ones training under the auspices of KONI (Indonesian national sports committee), have extra incentives and this is because the trainers must train according to the principles of practice, knowing every progress and setback in each individual athlete. It is even better if the coach understands physiology, psychology, and even biomechanics of every exercise, and also monitor athletes. During the activities of movement and play, athletes can develop their psychological and physical aspects including morals and social values of emotion, cognitive, and physical/motor. In principle, playing contains fun, happiness, without any coercion from outside the child's self, and more concerned with the process of exploring the potential of the self than the end result.

One of the sports that is under the auspices of KONI is FASI Aeromodelling, PORDIRGA. Aeromodelling FASI is an aerospace sports organization which is an organizational tool of PB FASI (Executive Board of Federation of Aero Sports Indonesia) that handles aeromodelling field with national authority. This organization also oversees the Aeromodelling Authority throughout Indonesia. Club aeromodelling stands under the auspices of each Pengda.

The results of the authors' observations from May 4-7, 2017 show that firstly, there is need for an exercise model involving the principles of practice such as FITT, the principle of avoiding excessive exercise doses, additional load principles, and individual principles. This is because the development of the athletes is not the only achievement but also the maintenance of the quality and health of the athletes as human beings by the trainers. technique training by the trainers towards achieving peak condition of players which have been determined through stages of periodesasi was found to be appropriate by 3 out of the 5 trainers that were researched while the remaining 2 representing $40 \%$ felt it was not appropriate. Regarding the contents of the exercise program for the 5 athletes, $80 \%$ answered that the contents were not appropriate, and $20 \%$ answered that they were appropriate. Based on the results and data analysis of the research, it can be concluded that the material content provided by the trainer can help athletes reach their peak but the program has a negative impact if it is being used for a long term, because it often produces more burden.

Keywords—evaluation, coaching, aeromodelling

Secondly, the trainers still lack the understanding of the principles of the exercise, with the result of the interview the trainers realize that there are frequent injuries to the arms and shoulders of the athletes but they are unaware of how to train safely with the principles of practice.

Thirdly, the PB FASI (Executive Board of Federation Aero Sports Indonesia) Aeromodelling itself does not upgrade the trainers and most of the trainers do not know how to train by using the principles of practice. So far, PB FASI (Executive Board of Federation Aero Sports Indonesia) Aeromodelling conducts upgrade for the referees only.

Based on the above problems, the researchers were encouraged to conduct a coaching evaluation on the exercise system based on science of coaching and exercise physiology of the PB FASI (Aero Sports Federation of Indonesia Federation) aeromodelling special for outdoor hand launched glider race numbers. The problems were analyzed using an evaluation research method.

\section{A. Aeromodelling}

Aeromodelling is an aerospace sports activity related to the planning, design, manufacture, and flight of the aircraft model. The aircraft model is an unmanned aircraft with certain restrictions that include limits of aircraft size, engine limitations, and form restrictions. Unmanned aircraft for reconnaissance purposes or for space missions, for example, by the military or space agency is referred to as Unmanned Aircraft or UAV, Unmanned Air Vehicle and this is not included in the category of aeromodelling.

With the statements that have been described above the author responded to the upgrading activities of trainers such as sports in general of course in accordance with the science 
of coaching and exercise physiology in order to minimize the occurrence of injury and humanize athletes themselves.

Results of interviews with the party PB FASI (Executive Board of the Federation Aero Sports Indonesia) PB showed that the board has never held any upgrading for coaches but engaged in training for referees.

\section{B. OHLG (Outdoor Hand Launched Glader)}

Responding to the above problems and according to the results of the in depth observation of many injuries found mostly only in the OHLG (Outdoor Hand Launched Glader) race number because the trainers do not know how to train in accordance with the principles and practice norms from the start of the volume of exercise, the intensity until the reps must be in accordance with existing rules.

The Out Door Hand Launched Glader aircraft is an aircraft model with the style that exists on the plane itself [1]. Flying is done by throwing it to reach a certain height in the air.

\section{Principles of Exercise}

The implementation of the principles of practice is based on the consideration according to [2] which states that the system of the body is capable of processing and adapting to physical exercise given over a period of time without experiencing injury.

Eevery coach will always try to improve the achievement of athletes as high as possible [5]. For that reason, the coach should constantly strive to improve his knowledge of the theory and methodology of his practice.

In accordance with the above statement the trainer should know the theory and methodology of the exercise. If it is too difficult to get the methodology, a trainer that knows only the physiology and exercise psychology is a great coach, even though, if the trainer cannot train in physiology, sports physiology management and organization to provide the team with the needed physiology and physical physiology to exercise safely and attain some level of achievement.

[8] suggests that, according to the above statement, even a great coach should understand the lifestyle of an athlete and his or her health habits. The trainers' understanding of the health of an athlete is very important. A trainer should be sensitive to the training schedule and body of an athlete so as to know when the athlete experiences pain based on congenital diseases or based on a very heavy workout. A trainer must understand the capacity of athletes, know when to stop and when to continue. The trainer must also be consistent with the principles and programs that can be used to measure athletes through viewing, assessing and evaluating them.

The main formation of muscle strength, pulmonary heart resistance, speed, and agility comes from physical fitness. Thus, physical fitness is more indicated for performance rather than health interests [5].

\section{Doses Exercise}

The principle of avoiding overloading is intended to prevent the exercise doses not to cause micro-injury, which if not properly treated will result in permanent injury, both anatomically and psychologically (overuse and traumatic syndrome) [2].
All the practices and programs that should be applied on an athlete should pay attention to the health and safety of the athlete so as to ensure that the athlete is in high spirit to take part in the practice which makes it easy for such athlete to attain the necessary achievements.

The application of individual principles is based on the fact that the physiological, psychological, and social characteristics of each person are different [4]. If a coach wants his athlete to achieve the greatest achievement and pay attention to every detail of the exercise, then the coach must also pay attention to every detail of the athlete ranging from the athlete's characteristic, psychic and social because a good coach must know the details of each athlete, his progress and his retreat as well as the physiological and psychological condition of the athlete.

The specific principle and sustaining dose of exercise is based on the fact that the body is unable to adapt to a sudden change in physical exercise doses which is far above its threshold [3]. In aeromodelling, exercises often occur in accordance with the exposure of Badriah above. As a result of this, the body will not be able to respond again in certain circumstances. The body will no longer respond to the exercise loading, especially if the athlete has experienced saturation and fatigue. The athlete must be left to recover from injury so as to heal mentally because, usually, when athletes experience this, they may not want to practice again.

The application of the basic principles of the exercise is reflected in the FITT arrangement (frequency, intensity, type of exercise and time). The purpose of this FITT principle is to give the body the opportunity to receive, respond to, and adapt the dose of exercise given, resulting in positive exercise effects [4].

\section{RESEARCH DESIGN}

CIPP (Context, Input, Proces, and Product) model developed by Stufflebeam with a qualitative method approach was used in evaluating the program for this research. This evaluation model was developed by Stufflebeam with the aim of assisting evaluators in evaluating programs, projects, and institutions. Evaluation is the process of drawing, discovering, providing descriptive information, consideration of the value and benefits of several objectives that have been planned, implemented and influenced to guide a decision, assess accountability, and understand phenomena.

\section{A. Subject And Informant}

The subject of a research are the people to be addressed for the research [2]. Research respondents are people who are asked to provide information about a fact or opinion. The data source in this study was the PB FASI board. The number of subjects in this study were 5 people. All subjects in this study were subjects who knew about PB FASI aeromodelling coaching system.

\section{B. Instrument Techniques and Data Collection Methods}

\section{Observation (observation)}

Observation is very important in knowing the real picture of the objects to be studied. Researchers use all the five senses to know the conditions of the objects of their research. 


\section{Interview}

Interviews are used to determine the exact conditions of the research object of the appropriate and reliable informants. Interview is a meeting of two people to exchange information and ideas through questions and answers, so that information on a particular topic will be retrieved.

\section{Documentation}

Document consists of several things that can help the research data. Documents, as secondary data, are obtained through data archives owned by PB FASI, and photos and matters aimed at supporting data accuracy.

\section{C.Instrument Validation and Reliability}

To obtain valid and scientifically reliable data, the data collected were checked for data validity. Testing the validity of data in qualitative research consists of the test, credibility (internal validity), transferability (external validity), dependability (reliability), and confirmability (objectivity).

\section{a. Test credibility (internal validity)}

The credibility test of data or trust to the data of qualitative research results, among others are done with an extension of observation, increased persistence in research, triangulation, discussion with peers, negative case analysis, and member check.

\section{b. Test Dependability (Reliability)}

A study is reliable if others can repeat or replicate the process of its research.

\section{c. Test Confirmability (Objectivity)}

The confirmability test in this study refers to the degree to which the researcher was able to show neutrality on the meaning/interpretation of the research results through confirmability audit by providing raw data, analytical records, and process notes. In this research, confirmability test was done by providing an audit trail in the form of a transcript of interview result, observation result, field note, data reduction result, research photos and documents attached at the end of the report.

\section{Data Analysis Technique}

Data analysis is a systematic process of data collection that has been obtained from various methods of data collection such as interviews, questionnaires, observation, and documentation". The technique used to conclude and analyze the research result was descriptive qualitative analysis. This data analysis technique was used to describe and interpret data from each component that evaluated qualitative data. Data from the interview was analyzed qualitatively.

\section{RESULTS}

The results show that the exercise program at Federation Aero Sports Indonesian does not yet have a good workout program because it is still not well organized. This can be seen from the training program that was given to the athlete which was not balanced with adequate breaks during the exercise. The exercise program was not adapted to the athlete's fatigue level, so injuries often occur. The data also shows that many athletes who are less able to maintain fitness was due to absence of break due to lack of supervision coach for the athletes. The result also reveals that the arrangement of physical and technical training programs by the trainers towards achieving peak condition for player which was determined through stages of period was found to be appropriate by 3 people out of 5 people representing $60 \%$ while the remaining 2 people representing $40 \%$ answered that it was not appropriate. Regarding the contents of the exercise program, $80 \%$ of the athletes answered that it was not appropriate, and $20 \%$ answered it was appropriate. Regarding the methods of field training program related to the guidance in the exercise of $70 \%$ achievement, and related to the evaluation of the exercise program of $60 \%$.

\section{CONCLUSION}

Based on the results and data analysis of the research, it can be concluded that the material content provided by the trainer can help athletes reach their peak but the program has a negative impact if it is being used for a long term, because it often produces more burden. The form of training prepared by the trainer is in accordance with the stages of practice for the period of training, however, the training method developed by the trainer was fully in line with the stages of the training period.

\section{REFERENCES}

[1] Z. Arifin, Evaluasi Pembelajaran. Bandung: Remaja Rosdakarya. 2014.

[2] S. Arikunto, Prosedur Penelitian Suatu Pendekatan Praktik. Jakarta: Rineka Cipta. 06, 2010.

[3] M. Amrozi, Evaluasi Manajemen Induk Organisasi Persatuan Bulutangkis Seluruh Indonesia (PBSI) Pemkot Malang Periode 20062010 dalam Porprov Jatim II, 2010.

[4] D. L. Badriah, Fisiologi Olahraga. Bandung:Multazam, 2011

[5] D. L. Badriah, Cedera Olahraga. Bandung:Multazam, 2013

[6] Harsono. Kepelatihan olahraga teori dan metodologi. Bandung: PT. Remaja rosdakarya, 2015

[7] M. Supriyanto, Bagaimana Membuat Dan Menerbangkan Pesawat Model Outdoor Hand Launched Glader Yogyakarta:Andi Yogyakarta, 2004

[8] F. Y. Tayibnapis, Evaluasi Program Pendidikan. PT Rineka Cipta, 2000

[9] Organization FASI, http://aeromodelling.or.id/about-us-mainmenu-2792410.html, diakses 05 desember 2017, pukul 22.14 WIB

[10] dan Jabar, C. S. A. Evaluasi Program. Jakarta: Bumi Aksara, . Dasar-Dasar Evaluasi Pendidikan. Jakarta: Bumi Aksara. Tesis, Universitas Negeri Malang, Malang, 2012

[12] K. McGee, Coaching basketball technical and tactical skills/American Sport Education. Champaig: Human Kinetics, 2007 